\title{
The Imperative of Integrating Corporate Business Plan with Manpower Planning
}

\author{
Francis C. Anyim \\ FCIPM, FNIM, FABS, FCAI \\ Lecturer, Department of Industrial Relations and Personnel Management \\ Faculty of Business Administration, University of Lagos, Nigeria \\ Tel: 234-803-346-8317_E-mail: chucksanyim2004@yahoo.com \\ Samuel E. Mba \\ Department of Industrial Relations and Personnel Management \\ Faculty of Business Administration, University of Lagos, Nigeria \\ Tel: 234-703-763-4818 E-mail: mbasam2011@yahoo.com \\ Joy O. Ekwoaba \\ Department of Industrial Relations and Personnel Management \\ Faculty of Business Administration, University of Lagos, Nigeria \\ Tel: 234-803-306-9753 E-mail: ekwoaba2002@yahoo.com
}

Received: December 22, $2011 \quad$ Accepted: March 14, $2012 \quad$ Published: April 16, 2012

doi:10.5539/ijbm.v7n8p56 URL: http://dx.doi.org/10.5539/ijbm.v7n8p56

\begin{abstract}
Traditionally, manpower planning as human resource activity is used by organizations to ensure that they have the right number and the right kinds of people, performing tasks at the right places and at the right time all in a bid to fulfill business objectives. Business plan seeks to identify the various factors critical to the success of the organization. It also focuses on how the organization can be better positioned and equipped to compete effectively in the market, while manpower planning, contributes to the business by providing the means (people) to accomplish the outcomes from the planning process.

This paper provides conceptual clarifications and examines the imperative of integrating business plan with manpower planning. It buttresses the need to strategically integrate the two plans as it ensures effective utilization of both human and material resources to achieve organizations aims and objectives in a rational manner. It concludes that manpower plan is intrinsically linked to business plan and that an organization can derive competitive advantage from the development of business plan that blends with the manpower plan. Lastly, recommendations for the effective interlink between the two plans were made to guide practitioners.
\end{abstract}

Keywords: Blending, Business integration, Interlink, Manpower, Planning

\section{Introduction}

Planning is the first and perhaps the most important function of any management, be it business, construction or even governing (Nwachukwu 1998). The essence of planning is to prepare for and predicts future events in any business set up. Planning goes beyond attempting to attain stated organizational objectives. It entails determination of control, direction and methods of accomplishing the overall business objective. A business man who wishes to embark on any business has to engage in detailed planning by drawing up a blue print for action. Planning has become more complex, particularly in this present time of increasingly turbulent business environments, which increases the tensions between the greater need for planning and the greater difficulties of prediction. Thus for must organizations, planning is increasingly the product of the interaction between line management and planners on one hand and human resource planners on the other. 
A business plan or policy is a formal statement which outlines the goals of the business, the reasons why they are believed to be attainable and also charting the path for reaching set goals. It may also contain background information about the organization. Business policy is a decision-making tool. It represents all aspects of business planning process. Furthermore, it could be a detailed description of a new or existing business, the company's product or service, marketing plan, financial statements etc. In a nutshell, it is a document that spelt out a company's expected course of action for a specified period and usually includes a detailed listing and analysis of risks and uncertainties. Christensen, Andrews and Bower (1973) define business policy as the duties, functions, roles and responsibilities of the general management level of the organization. It includes the study of the problems that affect and influence the character and success of the whole organization.

Manpower planning is a process of analyzing an organization human resource needs under changing conditions and developing the activities necessary to satisfy these needs (Walker, 1980). The aim of Manpower planning is to have the right number of staff at the right places with the right types of skills, at the right times to enable the organization achieve its short and long term goals.

Manpower planning is a subset of business or corporate planning and it is very important because the human element drives the entire gamut of the business. Furthermore, manpower is very influential and wields a lot of discretionary power in comparison to other operational factors that are passive. A well planned, nourished and revitalized manpower planning process can deliver the goods which in turn can achieve the twin goals of organizational and national development. In the light of the foregoing reasons, strategic integration is necessary in order to provide congruence between business and manpower strategy so that the latter supports the accomplishment of the former and, indeed, helps to define it. The aim is to provide strategic fit and consistency between the policy goals of the business and manpower planning.

\section{Literature Review}

Globalization and structural changes have been occurring more rapidly since the advent of the new millennium. Successful corporate management in these turbulent and competitive conditions require from management the development and adaptation of enterprise functional strategy; fast and consistent implementation of strategies in business plan and a high degree of flexibility and adaptability to changing business situations (Bent et al, 2005). Business plans should co-ordinate and describe specific milestones and a direction for the future success of the enterprise over several years. These plans should be well considered road map to the future of the enterprise and its constituent business components and they should be updated regularly (Taylor, 2008).

Manpower planning has been variedly defined by scholars. Maduabum (1998) sees it as a composite of activities that ensure the availability of adequate number and caliber of staff which an organization needs both for present and future requirements. According to Walker (1980) it is a process of analyzing an organization's human resources need under changing conditions and developing the activities, necessary to satisfy these needs. In the views of Ogunniyi (1992), it represents a critical analysis of supply, demand, surplus, shortages and utilization of human resources.

The integration of business and manpower planning is likely to be more appropriate in a stable market place with largely passive (and static) customers, and with scope for long-term forecasting because of the predictability of demographic change. This applies to many public sector enterprises and it is happening under the name of workforce planning (Employers' organization for local government, 2003). Linking manpower planning to business planning interprets these plans in terms of people requirement. However, it may influence the business strategy by drawing attention to ways in which people could be developed and deployed more effectively to enhance the achievement of business goals as well as focusing on problems that might have to be resolved to ensure that the people required will be available and will be capable of making the necessary contributions (Armstrong, 2009). In terms of forecasting, Taylor (2008) notes that employers quite simply prefer to wait until their view of the future environment clears sufficiently for them to see the whole picture before committing resources in preparation for its survival. The perception is that the more complex and turbulent the environment, the more important it is to wait and see before acting.

However, Farnham (2006) departed from Taylor on theory and practice. Farnham (2006) explains that manpower planning is important because it encourages employers to develop clear and explicit links between their business and human resources plans, and to integrate the two more effectively. It allows for better control over staffing costs and numbers employed and it enables employers to make more informed judgment about the skills and attitude mix in organizations. He expresses displeasure that organizations give little time to it because of lack of resources and skills, time and effort required and absence of relevant data to do so. Brian (2006) notes that a well integrated business plan seeks to address varying important issues. Guided by the business plan, the manpower 
planners will have a well designed and sound sourcing demand programme for different dates in future which then can be compared with the rough supply programmes by striking a balance. Dainty (2000) posits that the workforce plan saves the organization a lot of money at the same time add competent staff to the organization to surpass business target. In support of the foregoing view, Hunger and Wheelen (2003) state that manpower alignment implies integrating decisions concerning employees with decisions regarding the outcomes a business is attempting to reach in line with the objective of the company in relation.

Boxall and Purcell (2003) remark that human resource does not belong to HR specialist alone but also involves line managers who get result through people. In support, Armstrong (2009) states that human resource strategies are aligned to business objectives and integrated with one another through line managers and colleagues which stands on a daily basis to support the implementation of the business. On strategic role of human resource planners, Wright et al (2004) stated that they contribute to the development of business strategies. The emphasis on quantities, flows and mathematical modeling which appeared to be the main concern of manpower planning in the 60 's and 70s is at least complemented by and integrated with a qualitative view of people whose performance was at the core of business strategy (Legge, 2001).

The penalties of not staffing an organization correctly are costly. Understaffing loses the business economies of scale and specialization, orders, customers and profits. Overstaffing on the other hand is wasteful and expensive. If sustained, it is costly to eliminate because of modern legislation in form of redundancy payments, consultation, minimum period of notice etc. Very importantly, overstaffing reduces competitive efficiency of the business (Aina, 2005).

\section{The Role of Manpower Planning in a Dynamic Business Environment}

The organization first and foremost should be clear about its mission and objectives. The manpower planning must have a thorough blend with other business policies such as profitability, production, sales and development. Any change or alteration on the business objectives would certainly affect the manpower planning.

The ultimate aim of manpower planning should be to relate future human resource to future business plan or need so as to maximize the future return on investment. In sum, there must be congruence between business plan and manpower if the organization's vision, mission and objectives are to be achieved. Understaffing is inimical to the healthy growth and development of the organization. Overstaffing will equally have adverse effect on efficiency and productivity. Planning staffing level requires an assessment of the present and future needs of the organization and same linked to the current and forecasted resources. Appropriate steps are taken to bring demand and supply into balance. In this respect, the starting point is to take stock of the existing workforce profile (numbers, skills, ages, flexibility, gender, experience, capabilities, potential etc). The stock could be adjusted for one, three or ten years ahead as the case may be. This is done to make allowance for normal turnover, planned staff movements, retirements, discharge or separation etc. in line with the business trend for the corresponding time frame.

The result from the foregoing exercise will yield a series of crude supply situations and through the application of statistical analyses what future demands will be can be predicted. However, future staffing needs will derive from business plan and sales forecast; the effect of technology change on task needs; variations in the efficiency, productivity, flexibility of labour as a result of training, work study, organizational change, new motivations etc.

To justify the role of manpower planning, the following questions may be pertinent;

- What experiences does manpower have that are relevant to the business or project?

- What skills does manpower have that are relevant to the business or project?

- What weaknesses does manpower have as a team and individual and how will they be addressed?

- What type of succession plans are on ground to keep the business afloat?

\section{The Need to Integrate Business Policy with Manpower Planning}

Since the beginning of the $21^{\text {st }}$ century, there has been increasing claims that the route to competitive advantage is achieved through people. A crucial element in this assertion is the degree to which a link exists between HR practices with manpower planning inclusive and performance of the business. According to the Resource-Based - view of the firm, an organization can derive competitive advantage from its resources through the development of Human resource systems and routines which are unique to the organization.

In the 2000s, there is growing evidence that progressive HR practices can enhance a company's sustainable growth and profitability if there is integration with business purpose; although there is also evidence of a failure by many senior managers to recognize this (Boxall and Purcell, 2002). Business plans and strategy find their 
expression in measurable financial, marketing and production targets with an implicit or explicit demand for people. The manpower plan represents a response to ensure that the necessary supply of people is handy to allow targets to be achieved. Furthermore, manpower plan is expressed to fit the overall business strategy and plan by showing how the demand for people and their skills within an organization can be balanced with the supply side. By revealing complex factors, manpower planning becomes integrated into the whole process of management of employment relationship which plays a proactive part and affects organization's strategy, structure and practices.

Manpower plans are established against a predetermined strategy and they seek to make links between strategy, structure and people more explicitly. Integrating the manpower planning function with business plans means aligning decisions about people with decisions about business projection. The scenario creates room for the deployment of human resources activities that truly support organizational goals and objectives. As Quinn (1983) observes, manpower planning is a decision making process that combines three activities: identifying and acquiring the right number of people with the proper skills; motivating them to achieve high performance; and creating, interactive links between business objectives and of people planning activities.

In a nutshell, it is essential to blend manpower planning either at national or corporate level with business planning for the following reasons:

1) Work Demand: It is concerned with analysis, reviewing and attempting to produce the numbers and the kind of manpower needed by the organization to achieve its objectives. This concept is related to manpower and skills inventory which gives a clear analysis of those engaged in terms of number and skills employed by the organization in relation to the approved budget and dictates of the business plan.

2) Work Supply: This entails predicting what action will be necessary to ensure that the manpower need is available when required by business planners.

3) Linkages between Work Supply and Demand: This is concerned with designing the interaction between demand and supply so that skills are utilized to the best possible advantage and the legitimate aspirations of the individuals are taken into consideration.

4) Planning for Organizational Reasons: This involves communicating plans so as to obtain support/adherence to them, linking HR plans to business plans so as to influence each other, regaining corporate control over operating units, and coordinating and integrating organizational decision making and actions.

5) Organizational Change: In today's turbulent economic environment characterized by the fear of change and uncertainty, strategic planning in terms of manpower is a must. Such changes will generate changes in skills, job content, surplus or shortage of manpower etc.

6) Government Influence: State is said to be a necessary evil and hence has influence in the affairs of organizations due to some of its programmes targeted at correcting the ills of the past regarding working conditions, child and women labour, problem of unorganized, formal and informal sectors. These have galvanized organizations to understand and appreciate the imperative of genuine manpower planning.

\section{Areas of Priority for Effective Integration between Manpower and Business Planning}

\subsection{Recruitment}

How many and what types of people are required?

Should recruitment or internal development and transfer be preferred? And why? For instance, are there imbalances where transferring people would avoid a redundancy and encourage or support recruitment?

What problems exist with recruiting, and how might these be mitigated? Might less conventional contracts (such as job-share) tap new sources of recruit?

\subsection{Training and Development}

Given the number and types of people required, how desirable is it that they should be trained from within, and what is the capacity of the training and development system to deliver them?

Where will trainees come from - from among existing employees, through those already in the pipeline, or new recruits who will first have to be recruited?

How will trainees be selected, either from within or without?

What kind of training programme is required, what are the implications of taking people off-the-job, who will run it, how will it be resourced, what will it cost?

What are the requirements for developing people, such as managers, over the longer term? 


\subsection{Replacement}

Guided by the fact that there is no vacuum in life, we integrate manpower as a subset of business plans to achieve organizational plans. However, in case of redundancy / deaths / discharges / resignations / promotions / transfers and retirements, for the business plan not to suffer, it is imperative for the manpower planners to forecast how best to replace manpower needs.

The manpower plan is no less a detailed written document and a process set in train to deliver (or discard) specific number of people and skills. The plan may set targets and an outline timetable, but the detail will be filled in as people work through the implications asking questions such as the ones above. At this stage, it is vital then that proposed business actions in one area are continually tested against those in others to ensure a coherent and integrated response.

\subsection{Compensation Management}

This refers to financial and non-financial rewards that an employee receives in return for his labour or services to an organization. It is a complex and problematic issue in human resource management as it leads to strained relationship between labour and management in several occasions. Employees' compensation in whatever form remains a cost to the business and affects the profitability of the organization. However, to elicit the commitment of manpower to the organization, the compensation package must be perceived to be equitable in comparative terms.

\subsection{Motivation}

Most organizations give priority to what should be done or put in place to achieve and sustain high levels of performance through people. The business planners must give close attention to how the individuals in the organization can be motivated through incentive rewards, the work and its environment, leadership, mode of supervision etc.

\section{Recommendations for Effective Integration of Business with Manpower Planning.}

1) The hard aspect of manpower planning is based on quantitative analysis to ensure that the right number of people is available when needed. On the other hand, the soft aspect of manpower planning as described by Marchington and Wilkinson (1996) is more explicitly focused on creating and shaping the culture of the organization so that there is a clear integration between corporate goals and employees values and beliefs. To align both the hard and soft aspects of manpower planning, manpower requirements should be forecasted quantitatively and qualitatively with the qualitative aspect focusing on issues such as career development and planning, morale, motivation, diversity etc.

2) The manpower planners should not remain aloof from other operating or line managers. The manpower planners must work in partnership with line managers to ensure that manpower planning is integrated with other management functions. The alignment will guarantee better utilization of existing manpower and matching of skills with job requirements.

3) Manpower planners should design a parameter for measuring the contributions of manpower to business performance. Boxall and Purcell (2003) buttress the foregoing point by stating that the most potent action manpower managers can take to ensure that their strategic contribution is appreciated is to develop a measurement system that convincingly showcases manpower's impact on business performance.

4) There should be continuous rigorous and industry-related research on manpower planning. In this context, the manpower planning manager must be asking and pressing for answers to the following questions:

- What are the success factors in our organization and how can we identify and measure them?

- Have we developed a business plan in which everyone understands their respective roles in achieving the results and buys into it?

- What do we need to deliver the company to achieve its objectives?

- What specific actions and resources will be required? Are they available?

- What specific competencies are required and if there is short-fall, how will the competency-gaps be addressed.

- How will employees be rewarded for achieving result(s) amongst others?

5) In manpower planning, attempts should be made to ensure the accuracy of forecasts. If forecast are not accurate, planning will not be accurate. The inaccuracy of forecast increases when departmental forecasts are 
merely prepared without critical review of programmes and strategic needs to be developed for recruitment selection, training, internal transfers, promotions in order to meet future manpower requirements.

6) Manpower planning essentially requires full and wholehearted support from the top management. The manpower planners must work assiduously towards this end. In the absence of management support and commitment, the necessary resources and co-operation will be lacking. Consequently, manpower planning effort will be frustrated.

7) The manpower planning manager must be closely involved at management level where business plan is formulated and information obtained about the direction of the business. The manpower manager will be in a position to make contributions at an early stage about the manpower implications concerning the business plan and strategy. In other words, the manpower planners, should sit at the business table so as to enable them participate fully in the business planning process.

8) The quota system policy on employment in the public sector in Nigeria for instance should be abolished or at least watered down as it distorts strategic manpower planning in the public sector.

9) The educational system at the primary, secondary and tertiary levels should be reviewed continuously and emphasis placed on qualitative production of human resource rather than in quantitative terms. The manpower planning should focus on areas of high priority with inadequate manpower in order to enhance both corporate and national development.

10) It would be essential to ensure that the implication of change in one direction or aspect of business is considered for other aspect of manpower planning. For instance, acquisition of a new company raises questions about the issue of staffing, training, performance management etc.

\section{Conclusion}

Manpower planning is perhaps, the most critical factor of all requirements for integration as it has to be justified by the business plan and strategy. Where this is lacking, manpower planning will be perceived by top management and line managers as of little relevance to the real priorities of the business and the credibility of the manpower planners will be in doubt and could be questioned.

Manpower planning should be based on information concerning the business plan. For instance, external environment with particular reference to the supply of people (demographics) and the availability of skills should be the main focus of the manpower planner. HR issues in which manpower planning is domiciled could extend to productivity, motivation, commitment, employee relations etc.

For good business performance, it is important that manpower planners become a strategic partner with the business planners. For a long time, scholars in organizational development (OD) have maintained that improvement in business performance is directly tied to efficient manpower planning and closely linking the plan to strategic objectives. However, what some practitioners do not realize is that the answer is not necessarily on the application of the latest management principles but rather it is on the comprehensive integration of manpower planning with business plans and strategic objectives. This Quinn (1983) succinctly summarized as planning with people in mind.

To enhance manpower planning, the aim of manpower acquisition and retention should be to ensure on the one hand, that the achievement of corporate objectives will not be inhibited by manpower shortages or inefficiencies and, on the other, that impending surpluses can be dealt with in good time with minimum individual hardship and disruption to employee relations. That is what the blending of business with manpower planning should stand out to achieve in both the short and long term.

\section{References}

Aina, S. (2005). Managing Human Capital in Nigeria. Lagos: Fountain Training.

Armstrong, M. (2009). Handbook of Human Resource Management Practice. (11th ed.). London: Kogan Page.

Bent, F., Mette, K., Skamris, H., \& Soren, L. B. (2005). How Inaccurate are Demand Forecasts in Public Works Projects?. Journal of the American Planning Association, 71(2), 131-146. http://dx.doi.org/10.1080/01944360508976688

Boxall, P. F., \& Purcell, J. (2003). Strategy and Human Resource Management. Basingstoke: Palgrave Macmillan.

Brian, F. (2006). How to Write a Business Plan. (2nd ed.). London: Kogan Page.

Christensen, C. R., Andren, K. R., \& Bower, J. T. (1973). Business Policy. Irwin Inc. 
Dainty, A. (2000). Improving Employee Sourcing within Construction Organization. In Proceedings of the ARCOM 2000 Conference, Glasgow, Vol.1.

Employers' Organization for Local Government. (2003). Guide to Workforce Planning in Local Authorities.

Farnham, D. (2006). Examiner's Report (May). CIPD Co., UK.

Hunger, T. D., \& Wheelen, T. (2003). Essentials of Strategic Management. New Jersey: Pearson Education Inc.

Legge, K. (2001). Silver Bullet or Spent Round? Assessing the Meaning of the High Commitment Management/Performance Relationship. In Storey, J. (ed.), Human Resource Management: A Critical Text (2nd ed.).

Maduabum, C. P. (1998). Perspectives on Manpower Planning and Development in Nigeria: Text and Cases. Badagry ASCON Press.

Marchington, M., \& Wilkinson, A. (1996). Core Personnel and Development. Institute of Personnel and Development, London.

Nwachukwu C. C. (1998). Management Theory and Practice. Onitsha: Africana - FEP Publisher Ltd.

Ogunniyi, O. (1992). Manpower Planning Issues and Problems in Nigeria. In Ali, D. Y., \& Caleb, I. Akinyele (eds.), New Trends in Personnel Management: A Book Readings. Badagry: ASCON Press.

Quinn, M. D. (1983). Planning with People in Mind. Harvard Business Review, Nov. - Dec.

Taylor, S. (2008). People Resourcing. London: CIPD.

Walker, J. (1980). Forecasting Manpower Needs. Harvard Business Review, March - April.

Wright P. M., Snell, S. A., \& Jacobsen. (2004). Current Approaches to HR Strategies: Inside-out Versus Outside - in. Human Resource Planning, 27(4), 2-22. 